\title{
Managing Egypt's Poor and the Politics of Benevolence, 1800-1952
}

\author{
Mine Ener \\ Princeton, NJ: Princeton University Press, 2003. 195 pages.
}

In Egypt and elsewhere in the Ottoman Empire, the social safety net represented by the extended family branched off in many directions. By Mamluk times, it encompassed the patronage of wealthy and noble families who distributed food to the poor on religious festivals and during times of hardship, and who sponsored the construction of bridges, waterworks, and public fountains. In addition, mosques sometimes housed schools, soup kitchens, and hospitals; merchants regularly fed beggars; Sufi lodges housed travelers; and waqf endowments sponsored various religious and charitable activities. Ruling dynasties, including their women, created funds that sponsored orphans' homes, paid the dowries of poor women, and provided pensions for the widows and children of soldiers killed in battle.

As Ener shows in her valuable and carefully researched book, the values of $i$ san (generosity) and sadaqah (almsgiving) have been applied according to ideas about charity's legitimate beneficiaries (e.g., clerics, the poor, orphans, and women without family support). Ener traces the fortunes of the poor, the changing constellation of institutions available for their relief, and the transformation in Egyptian understanding of those entitled to such care.

By the middle of the nineteenth century, the traditional "mixed economy" of relief (p. 9), which incorporated countless donors and institutions, operated alongside a more centralized set of interests and practices intended to control poor people's movement and activities. Such practices had not been common previously (p. 15) and appear to have been unique in the Middle East (p. 29). Authorities began to distinguish between the deserving and the undesirable poor and sought to prevent able-bodied men from encroaching on urban space as beggars or "fake" mendicants and from using publicly available forms of assistance. In nineteenth-century Cairo and Alexandria, such men and peasants "absconding" from the countryside were often arrested, sent back to their home regions, and pressed into involuntary agricultural, industrial, or military service. The growing modern state was increasingly interested in controlling crime, immigration, and the flow of disease through internationalized urban spaces.

Ener focuses largely on Egypt's four state-sponsored institutions for poor relief nationwide: the Maristan Qalawun, founded in 1284; Takiyyat Tulun, within the historic mosque of Ibn Tulun; the Qishlah al-Sadaqah; 
and Takiyyat Qabbari. Their inhabitants consisted of individuals who had petitioned the police or other authorities for entry and those who had been arrested for vagrancy on the streets. For some, these shelters were temporary homes; for others, they were more or less permanent residences. Their capacity was always limited. Takiyyat Tulun, for example, could house up to 600 people from the time it was first used as a shelter in 1847-48 until it was closed prior to 1880 to preserve its architecture.

The increased demand for government poor relief was met with increasingly stringent eligibility requirements (although that demand itself was at least partially the result of the government's military conscription policies, which deprived families of their breadwinners and sometimes thrust them into poverty). Doctors employed by Cairo's civilian hospital and its central police office were made responsible for evaluating the petitioners' health status and needs. Those admitted were judged to be in a state of dependence (orphans, single women, the elderly and invalid, men with children) and received sparse rations that fluctuated with the state's budgetary fortunes.

By the late nineteenth century, the idea that the ruler's benevolence should be the primary source of large-scale bureaucratized poor relief began to change as Egypt's growing educated and nationalistic middle classes organized their own relief efforts. Confessional, national, and ethnic groups (e.g., Copts, Armenians, Syrians, and Jews) had long carried out charitable works within their own communities. But now, embarrassed by what European visitors saw as "the spectacle of the poor" in Cairo's streets and concerned by the British occupation government's further cutting of social welfare programs, Egyptian elites used private organizations like Alexandria's Muslim Benevolent Society, founded in 1879, to care for the deserving.

Particularly after the First World War, the activitites of these societies, "directed toward the care of children, took place within a discourse of national unity and citizenship rather than necessarily within a framework of religious obligations to the poor" (p. 98). Nurturing, healing, and educating the nation's children was an act of national defense. The flowering of multiethnic charitable associations and professional syndicates, as well as new kinds of religious associations (both the Muslim Youth Association and the Mus-lim Brotherhood were founded in 1928), after the 1919 revolution was not merely an issue of responding to greater demand. Rather, it signified an increased social competition among Egypt's elites (p. 121) and the maturation of a language of national obligation.

Threatened by the growth of autonomous and socially active organizations, in 1939 King Farouk's government took control of Egypt's private associations by establishing the Ministry of Social Affairs. According to a 
ministry publication, Egypt's social problems needed a rational and unified approach, "a comprehensive and permanent policy of social rehabilitation with a view to uplifting the poor classes, raising the standard of living ... and finally assuring ... social justice to the people" (p. 130). This strategy of control persisted throughout the period covered by this book and is still in force.

Ener's important and perceptive book provides social and political historians with both a valuable body of data and a nuanced approach to how religious and cultural values, social traditions and economic resources, and domestic and international political structures have intersected in shaping poverty alleviation practices. Importantly, she approaches this task not only through a reconstruction of official efforts but, as much as possible, through a close reading of contemporary police records in an attempt to recapture the voices and experiences of the poor themselves.

Gregory Starrett 